ACTA THERIOLOGICA

Vol. 25, 2: 25-30, 1980

\title{
Nerve Centres of the Cerebellum in the Mole and Common Shrew
}

\author{
Zofia SKRZYPIEC \& Marek JASTRZĘBSKI
}

\begin{abstract}
Skrzypiec Z. \& Jastrzębski M., 1980: Nerve centres of the cerebellum in the mole and common shrew. Acta theriol., 25, 2: 25-30 [With Plate III].

A description is given of the structure and topography of cerebellar nuclei in the mole (Talpa europaea Linnaeus, 1758) and commnn shrew (Sorex araneus L innae us, 1758). Studies have shown that the structure of the cerebellar nuclei is similar in these two species. In the shrew nucleus medialis is an independent band of cells, while nucleus lateralis and interpositus are joined by their anterior parts. In the mole all nuclei join in the anterior part, while the posterior parts run independent courses. It was also found that cells included in the composition of the nuclei described are mostly larger in the shrew than in the mole.

[Inst. Biol., Univ. M. Curie-Skłodowskiej, ul. Akademicka 19, 20-033 Lublin and Inst. Anim. Anat., Agric. Acad., ul. Akademicka 12, 20-033 Lublin].
\end{abstract}

Studies on the morphology of the cerebellum, an important centre of motor coordination, have been carried out on numerous species. The animals chosen for the studies described below belong to the Insectivora order, but differ fundamentally in respect of their way of life (the mole leads a subterranean, and the shrew an above-ground way of life), and undoubtedly also as regards the range of movement of the limbs, and activity. It is thus possible that the structure of cerebellar nuclei in these two species may also exhibit certain differences.

Two cerebella (male and female) of the mole (Talpa europaea Linnaeus, 1758) and two (male and female) of the shrew (Sorex araneus Linnae us, 1758) were used for the studies. The animals were sexually mature. After fixing in Bouin fluid and alcohol the cerebella were embedded in paraffin, sectioned to $5 \mu \mathrm{m}$, and stained by the Kluver and Barrera method. All the sections were taken for examination.

\section{RESULTS}

The structure of cerebellar nuclei in the mole is not very diversified. The length of the whole group of nuclei is about $1.2 \mathrm{~mm}$, to the rear from the posterior boundary of the fastigium there is a part about $0.4 \mathrm{~mm}$ in length. Three fairly distinct bands of cells can be distinguished 
in the posterior part: nucleus lateralis and nucleus medialis with nucleus interpositus, which is far shorter than the others, lying between them (Fig. 1). Nucleus medialis and lateralis begin at the same level, nucleus interpositus - further forward, far closer to the posterior boundary of the fastigium. Nucleus medialis is a fairly narrow band rounded in cross-sections but more oval further forward. Near the fastigium a fairly faint division into groups - the dorsal small, spherical and ventral -

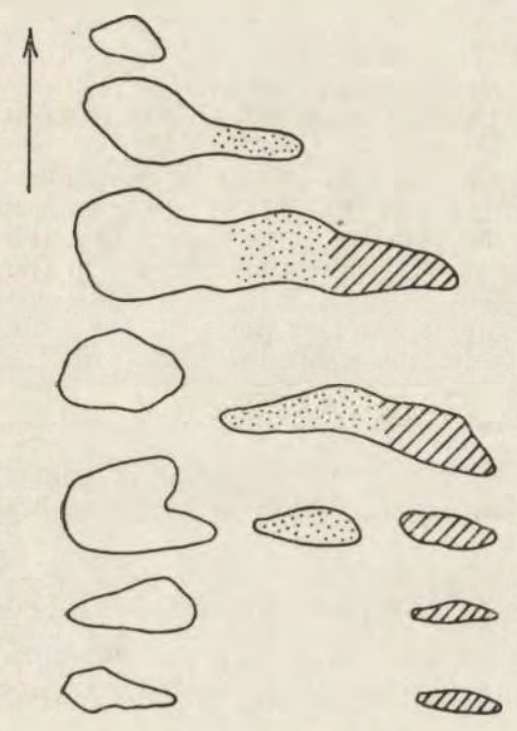

Talpa europaea L.
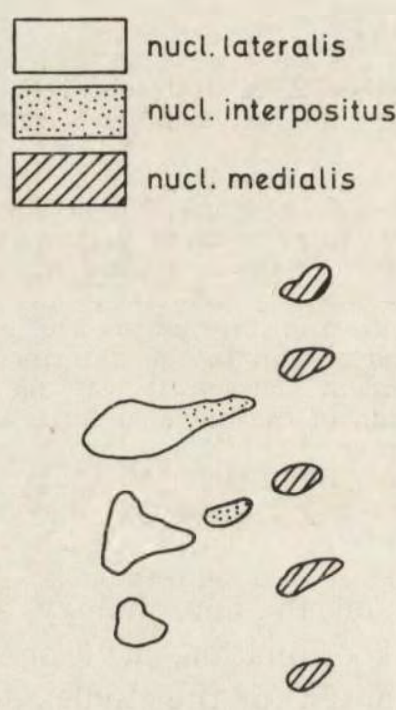

$300 \mu \mathrm{m}$

Sorex araneus $\mathrm{L}$.

Fig. 1. Cross-sections of the cerebellar nuclei in the mole and common shrew. Arrow indicate nasad direction

and the larger, oval - can be seen over a short part of the nucleus. Cranially the groups combine to form a homogeneous concentration with oval cross-sections. Nucleus lateralis is better developed. It constitutes a thick band, spherical in cross-sections, near the posterior end, and further forwards - similar in shape to a thick crescent with its horns directed upwards. Nucleus interpositus is a short, homogeneous band with a round or irregular outline when seen in cross-section. Slightly further towards the anterior from halfway along the length of the whole group of nuclei it connects with nucleus medialis to form a horizontally positioned group. Further forwards nucleus lateralis alsc. 
joins the group formed in this way. From this place onwards the connected nuclei are shaped like a dorso-ventrally flattened plate, first of all broad, narrowing forwards and moving sideways. The anterior end is formed by a small spherical group of cells lying in the lateral part of the cerebellar medulla.

Cells included in the composition of the cerebellar nuclei in the mole are triangular, spherical or fusiform (Photos $1-3$ ); and vary in dimensions from 10 to $20 \mu \mathrm{m}$. Large cells of up to $30 \mu \mathrm{m}$ in size occur in nucleus lateralis. The cells contain large but not very distinct nuclei with a very faintly visible nucleolus. Distinct granules can be seen in the cell nuclei.

The cerebellar nuclei in the common shrew are very similar in structure to the nuclei of the mole cerebellum (Fig. 1). The length of the whole group of these nuclei is about $0.8 \mathrm{~mm}$, with a part about 0.3 $\mathrm{mm}$ lying to the rear of fastigium. Nucleus medialis is an independent, elongated and homogeneous band, the posterior end of which reaches furthest to the rear, while nucleus lateralis begins at a slight distance to the :ear of the fastigium, and nucleus interpositus slightly forwards of this point. Nucleus medialis is oval in outline seen in cross-section, but rovnded in its middle, widest part. The cells of the posterior part are more closely arranged than in the anterior part. The anterior part of nucleus medialis consists of loosely scattered cells, and is irregular in outline when seen in cross-section. The anterior end of the nucleus is clearly defined and lies further back than the anterior end of nucleus lateralis. Nucleus lateralis is elongated, the posterior part running independently, while the anterior part coalesces with nucleus interpositus. The part of the nucleus lying to the rear of fastigium is first round, then oval in cross-sections. Forwards from the posterior boundary of fastigium this nucleus divides into two groups running parallel to each other, the dorsal group of which being several times thinner than the ventral and visible over a short part. After disappearance of the dorsal group nucleus lateralis becomes a thick, homogeneous band in which large cells are grouped in the dorsal part, and small cells in the ventral. Nucleus interpositus is a very short band coalescing in its anterior end with nucleus lateralis. The boundary between the two nuclei can be drawn on the basis of their cytostructure since nucleus interpositus cells are far smaller and more closely arranged. After the two nuclei join, the group thus formed is similar in shape in the cross-section to an elongated triangle with its apex directed medially. The group of small cells forming an extension of nucleus interpositus disappears earlier than the remaining part, consisting of the large cells characteristic of nucleus lateralis. The anterior end forms a small narrow band. Cerebellar nuclei in the shrew are formed of triangular cells, which in nucleus lateralis 
attain measurements of up to $30 \mu \mathrm{m}$ (Photo 4). Triangular spherical and fusiform cells up to $20 \mu \mathrm{m}$ in length occur in nucleus medialis (Photo 5). Small spherical cells occur in all three nuclei and particularly in nucleus interpositus (Photo 6), and the ventral part of nucleus lateralis. reaching dimensions of 10 to $12 \mu \mathrm{m}$. The cell nuclei are large with a distinct nucleolus, tigroid matter is finely granulated or fills the cells with a formless mass.

\section{DISCUSSION}

The studies made showed that the cerebellar nuclei in the mole and common shrew are relatively slightly differentiated in structure. Species differences apply in this case chiefly to the extent of the nuclei and their relative length but also, although to a lesser degree, to the degree of development.

The cerebellar nuclei in the common shrew exhibit slightly stronger development in the mole. Nucleus medialis is relatively the longest and, although its structure is not differentiated, it was noticed that the cells are fairly closely arranged in the posterior part of the nucleus but are loosely scattered in the anterior part. This nucleus is an independent band of cells and does not connect with the other nuclei, as it does in the mole. Over a very short part of nucleus lateralis there are two groups of cells - dorsal and ventral, but this is not observed in the mole. In addition in nucleus lateralis of the common shrew there is a distinct dorsal zone in which large cells occur and a ventral zone consisting of small cells. The difference between the two species in respect of cell structure of the cerebellar nuclei is fairly distinct. In the common shrew cells of up to $30 \mu \mathrm{m}$ occur, this applying particularly to nucleus lateralis. In the mole large cells - about $30 \mu \mathrm{m}$ - occur in far smaller amounts. Dimensions of cells in shrew cerebellar nuclei usually measure up to $20 \mu \mathrm{m}$, and in the mole - approximately $15 \mu \mathrm{m}$.

Our observations do not confirm the results of studies by Brunner (1911), who found only one, homogeneous nucleus to occur in Insectivora. In both the shrew and the mole the division of the nuclei in the posterior part is very distinct, and can also be defined in the anterior part on the basis of cytostructure. Attention to cytostructural differences has also been drawn by Bujak (1971) in the horse, Flood \& Jansen (1961) in the cat and Jastrzębski $(1965,1966)$ in certain rodents and domestic ruminants.

The cerebellar nuclei in the species examined are far less strongly developed than in rodents ( $\mathrm{J}$ a st rzę bs ki, 1965), in which three distinctly separated nuclei, differing in respect of cytostructure, occur. 
The differences in the structure of cerebellar nuclei in these species, although slight, are distinct and suggest that this may be connected with the way in which the shrew and the mole move about and the habitat in which these animals live. The mole's activities below ground and the exact adaptation of its limbs to the somewhat limited range of movements required to excavate subterranean tunnels would appear to require a slightly lesser degree of movement coordination than the walking or running about of so active an animal as the common shrew.

\section{REFERENCES}

1. Brunner H., 1911: Die zentralen Kleinhirnkerne bei den Säugetieren. Arb. Neur. Inst. Wien, 22: 200-218.

2. Bujak A., 1971: Topografia i cytoarchitektonika jąder móżdżku konia. Poi. Arch. Wet., 14: 613-622.

3. Flood S. \& Jansen J., 1961: On the cerebellar nuclei in the cat. Acta Anat., 46: 46-52.

4. Jastrzębski M., 1965: Jądra móżdżku niektórych Microtidae (Rodentia). Annls Univ. M. Curie-Sklodowska, C, 20: 167-178.

5. J a strzę bski M., 1966: Jądra móżdżku przeżuwaczy domowych. Annls Univ. M. Curie-Skłodowska, DD, 21: 263-278.

Accepted, September 25, 1979.

Zofia SKRZYPIEC i Marek JASTRZĘBSKI

OSRODKI NERWOWE MOŻDŻKU KRETA I RYJOWKI AKSAMITNEJ

\section{Streszczenie}

Opisəno budowę i topografię jąder móżdżku kreta (Talpa europaea L in na e u s, 1758) i ryjówki aksamitnej (Sorex araneus Linnae us, 1758). Badania wykazały, że u obu gatunków jądra móżdżku mają budowę zbliżoną. U ryjówki aksamitnej jądro przyśrodkowe jest samodzielnym pasmem komórek, a jądro boczne i wsunięte łączą się swymi przednimi odcinkami. U kreta wszystkie jądra łączą się w przedniej części, natomiast odcinki tylne biegną samodzielnie (Fig. 1). Stwierdzono również, że komórki wchodzące w skład opisywanych jąder u ryjówki aksamitnej są przeważnie większe niż u kreta (Plate III). 


\section{EXPLANATION OF PLATE}

\section{Plate III}

Cell structure in the cerebellar nuclei of the mole (Photos 1, 2, 3) and common shrew (Photos 4, 5, 6). Magn. 300×.

Photo 1, 5 - nucleus medialis, Photo 2, 4 -- nucleus lateralis, Photo 3, 6 nucleus interpositus. 


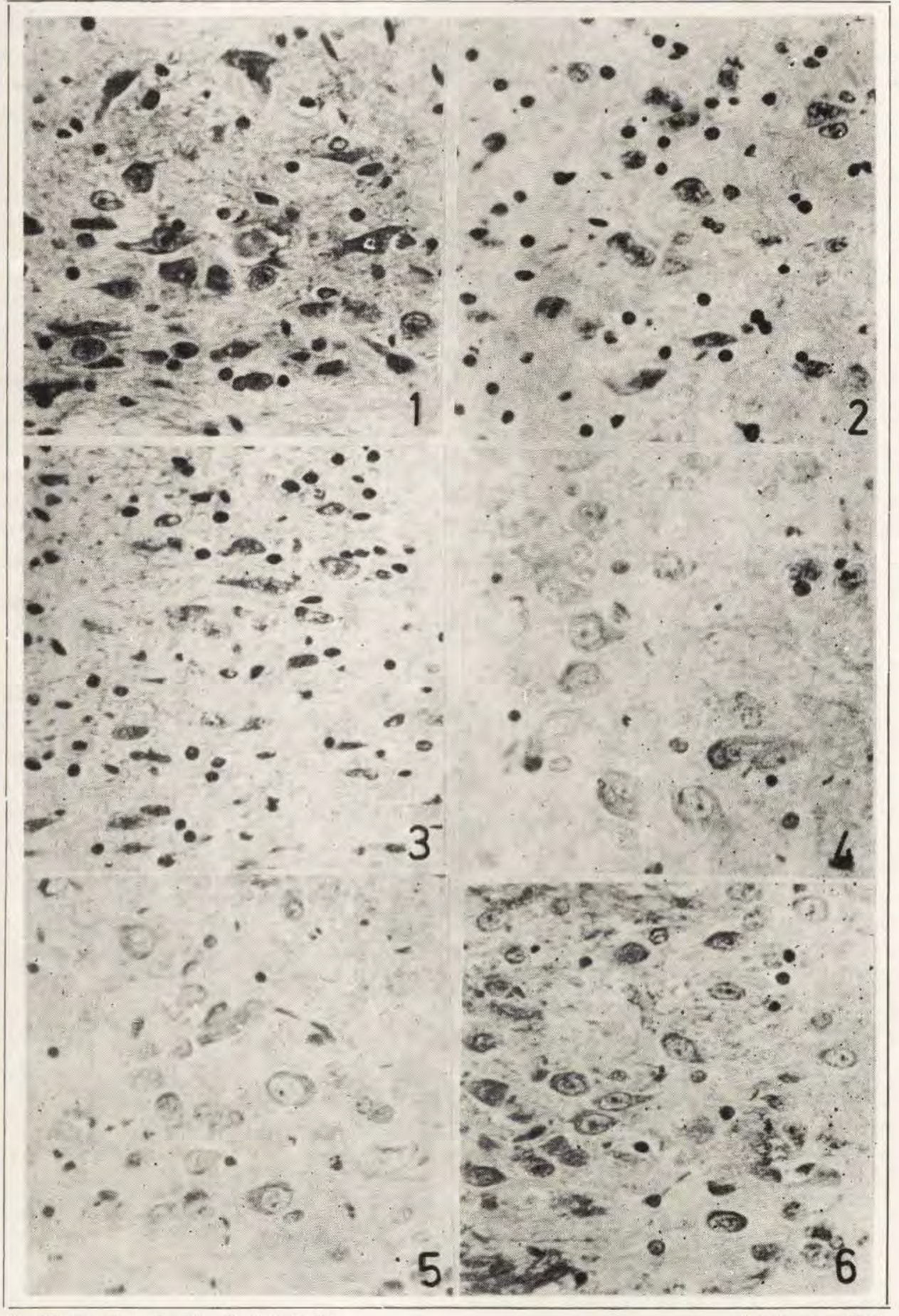

Z. Skrzypiec \& M. Jastrzębski 